\title{
High-performance liquid chromatographic assay of serum glycated albumin
}

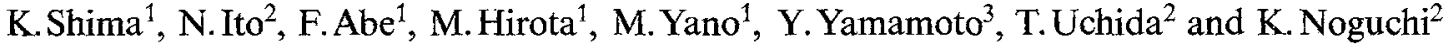 \\ ${ }^{1}$ Department of Laboratory Medicine, Tokushima University School of Medicine, Tokushima, \\ ${ }^{2}$ Gel Separation Development Department, Asahi Chemical Industry Co, Kawasaki, and \\ ${ }^{3}$ Department of Medicine and Geriatrics, Osaka University Medical School, Osaka, Japan
}

\begin{abstract}
Summary. A method for determination of serum glycated albumin by high-performance liquid chromatography is presented. The system involves anion exchange chromatography to separate albumin and consecutive boronate affinity chromatography to separate glycated and nonglycated albumin. The method is rapid ( $20 \mathrm{~min}$ ), precise (coefficient of variation, $0.7-4.9 \%)$, requires only a small sample $(5 \mu \mathrm{l})$, and can be automated. Assay of glycated albumin by this method is not influenced by the protein concentration of the sample or the presence of glucose. The variation in glycated albumin values in consecutive samples obtained within a day from diabetic patients (coefficient of variation, $2.02 \pm 0.65 \%$ ) was significantly smaller $(p<0.001)$ than that of values for fruc-
\end{abstract}

tosamine (coefficient of variation, $4.33 \pm 2.0 \%$ ). The values of glycated albumin in normal subjects $(20.2 \pm 1.6 \%)$ were clearly less than those in diabetic patients $[39,6 \pm 5.4 \%$ in 40 Type 1 (insulin-dependent) and $39.4 \pm 5.9 \%$ in 25 Type 2 (non-insulin-dependent) patients]. The serum glycated albumin level was well correlated with $\mathrm{HbA}_{1 \mathrm{c}}$ in 65 diabetic patients $(r=0.60)$. Because the life span of albumin in the circulation is short, measurement of glycated albumin should be useful as a short-term index of glycaemic control.

Key words: Affinity chromatography, anion exchange chromatography, fructosamine, haemoglobin $A_{1 c}$, glycaemic control, glycated protein.
Glycation of proteins can occur as a non-enzymatic post-translational modification $[1,2]$ directly dependent upon the prevailing glucose concentration. From the diagnostic point of view, non-enzymatic glycation of albumin and other plasma proteins appears to provide an index of the state of glycaemic control about two weeks previously, and may be useful clinically in the same way as measurement of glycated haemoglobin [3-11]. The level of glycated albumin (GA) should provide additional useful information on glycaemic control when monitoring the effect of change in diet or insulin therapy. Serum glycated protein rather than glycated albumin has been measured because of the difficulty in separating albumin from other serum proteins. But since the exact half-lives of all glycated proteins have not yet been determined, measurement of GA may be more useful clinically because its half-life is known. However, the various methods for measurement of GA reported so far $[3,4,12]$ are laborious, and unsuitable for routine clinical use.

Therefore, we devised a simple high-performance liquid chromatographic (HPLC) method for separation of GA involving a combination of ion exchange chromatography to separate albumin and boronate affinity chromatography to separate GA from non gly- cated albumin (non-GA). Then we used this method to measure the GA levels in clinical samples and compared the values with those for fructosamine, which is regarded as an index of glycated protein.

\section{Materials and methods}

\section{Materials}

Asahipak ES-502N (high-performance anion exchange chromatography column, $100 \times 7.6 \mathrm{~mm}$ ), which is commercially available, and Asahipak GS-520 gel (exclusion limit of molecular weight, $3 \times 10^{5}$; particle size, $9.0 \pm 0.5 \mu \mathrm{m}$ ) were products of Asahi Chemical Industry (Kawasaki, Japan). Epichlorohydrin was obtained from Tokyo Chemical Industry (Tokyo, Japan). $m$-Aminophenylboronic acid hemisulfate salt was purchased from Sigma Chemical Co. (St.Louis, Mo, USA),

\section{Preparation of affinity adsorbent for glycated albumin (Asahipak GS-520-Boronate)}

Activation procedure. Dried Asahipak GS-520 gel ( $80 \mathrm{~g}$ ) was suspended in $800 \mathrm{ml}$ of dimethyl sulfoxide. Then $374 \mathrm{ml}$ of epichlorohydrin and $40 \mathrm{ml}$ of $10 \mathrm{~mol} / 1$ sodium hydroxide solution were added with stirring at $30^{\circ} \mathrm{C}$ for $20 \mathrm{~h}$. The activated gel was washed with 11 dimethyl sulfoxide and 21 water. 

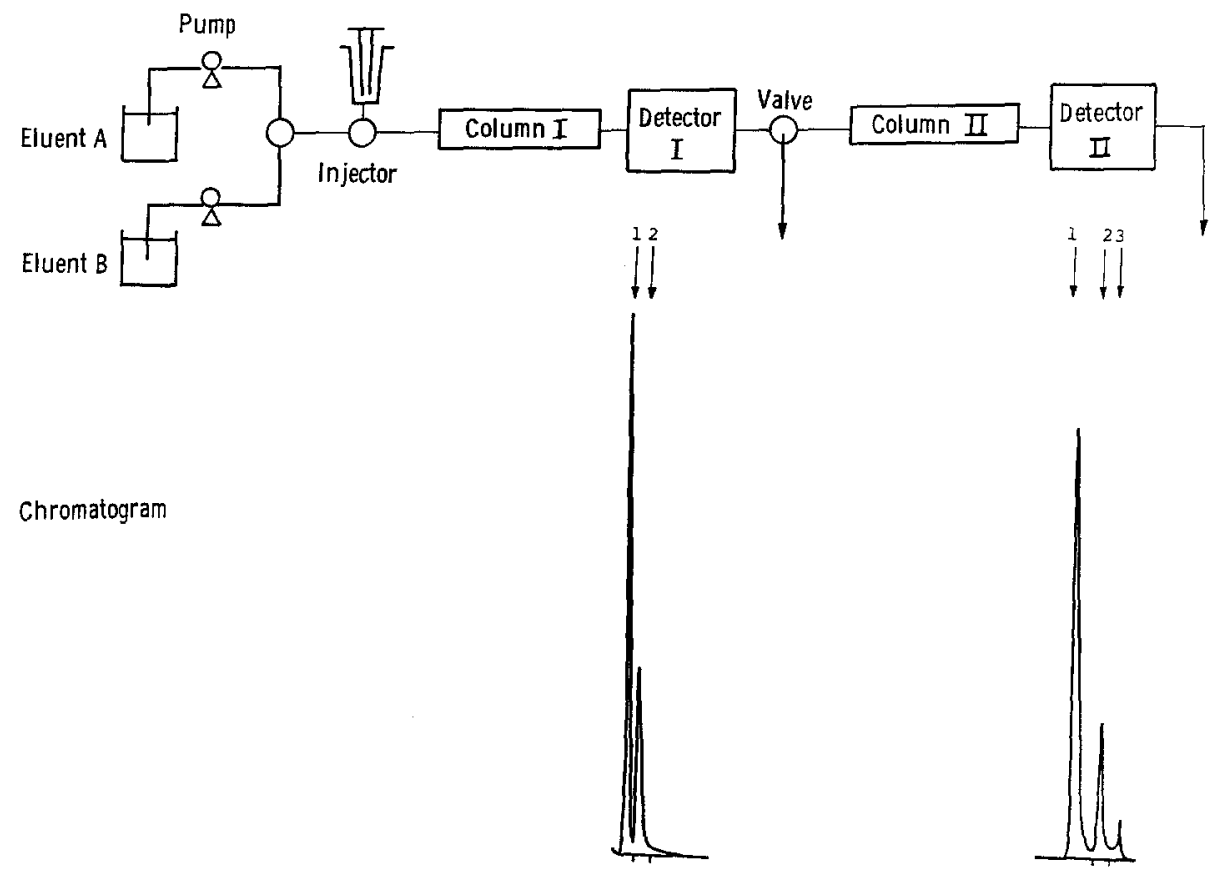

Fig. 1. Schematic diagram of the chromatographic system and chromatograms. Column I, an anion exchange column, separates albumin (peak 2 in the first chromatogram) from other serum components. The albumin component is then introduced into Column II, a boronate affinity column, in which the second chromatogram is obtained. Glycated albumin (peak 2 in the second chromatogram) is expressed as a percentage of the total albumin (peaks 1 and 2 in the second chromatogram). For details, see "Materials and methods"

Coupling of m-aminophenylboronic acid. The activated gel $(40 \mathrm{~g})$ was suspended in $100 \mathrm{ml}$ of water, and $26 \mathrm{~g}$ of $m$-aminophenylboronic acid hemisulfate salt was added. The $\mathrm{pH}$ was adjusted to 10 with $1 \mathrm{~mol} / 1$ sodium hydroxide solution and the suspension was stirred at $60^{\circ} \mathrm{C}$ for $20 \mathrm{~h}$. The adsorbent was then washed with 11 water. The content of $m$-aminophenylboronic acid was $290 \mu \mathrm{mol}$ per g dry gel, which was determined by titrating boronic acid liberated from the gel by the addition of hydrogen peroxide with sodium hydroxide.

Chromatographic system. The adsorbent was packed in a stainlesssteel column $(100 \times 6 \mathrm{~mm})$. The following eluents were used: Eluent A, 5\% ethanol solution containing $250 \mathrm{mmol} / 1$ ammonium


$200 \mathrm{mmol} / 1$ sorbitol, $100 \mathrm{mmol} / 1 \mathrm{tris}$ (hydroxymethyl)aminomethane and $50 \mathrm{mmol} / 1$ EDTA-2Na (pH 8.50). The eluents were degassed by the use of an on-line degassing unit (DEGAS, Showa Denko, Tokyo, Japan), und introduced at a flow rate of $1.0 \mathrm{ml} / \mathrm{min}$ using HPLC pumps (LC-6A, Shimadzu, Kyoto, Japan).

A diagram of the system is shown in Figure 1. Both columns were immersed in a water bath $\left(30^{\circ} \mathrm{C}\right)$. A 10 -min convex gradient program from Eluent $A$ to $70 \%$ Eluent $B$ was started 10 min after injection of $5 \mu$ l of sample with an injector (Model 7125; Rheodyne, Cotati, Calif, USA) into the Asahipak ES-502N column. The effluent was passed through a fluorescence monitor (Detector I; Xenon lamp; excitation wavelength, $285 \mathrm{~nm}$, emission wavelength, $340 \mathrm{~nm}$; RF-530, Shimadzu). After the first fraction had drained off, the fraction containing albumin was introduced into the column of Asahipak GS-520-boronate by use of a high-pressure valve (FCV-2AH, Shimadzu). The two pumps and valve were controlled with a system controller (SCL-6A, Shimadzu). The effluent from column II was passed through another fluorescence monitor (Detector II; RF-530; Shimadzu). The outputs from the two monitors were processed with an integrator (SIC-7000 A, System Instruments, Kyoto, Japan). GA values are expressed as percentages of the glycated form (peak 2 in the second chromatogram in Fig.1) in the total albumin (peaks 1 and 2 in the second chromatogram in Fig.1). One run required about 20 min.

Precision was evaluated using serum samples with low and high GA levels (Table 1). The values for the two serum samples were measured 10 times during an analytical run within a day to determine the within-day precision. For evaluating the between-day precision, we measured the GA levels in different samples in successive analytical runs on different days.
Table 1. Reproducibility of the present assay

\begin{tabular}{lllr}
\hline & Within-day & \multicolumn{2}{l}{ Between-day } \\
Sample & A & B & C \\
\hline mean & 19.16 & 55.69 & 20.63 \\
SD & 0.72 & 0.39 & 1.02 \\
CV (\%) & 3.77 & 0.70 & 4.94 \\
\hline
\end{tabular}

Table 2. Clinical characteristics of the subjects

\begin{tabular}{|c|c|c|c|c|}
\hline Group & $\begin{array}{l}\text { Age } \\
\text { (years) }\end{array}$ & $\begin{array}{l}\text { Sex } \\
(\mathrm{M} / \mathrm{F})\end{array}$ & $\begin{array}{l}\text { Fasting blood } \\
\text { glucose } \\
(\mathrm{mmol} / 1)\end{array}$ & $\begin{array}{l}\mathrm{HbA}_{1 \mathrm{c}} \\
(\%) \\
\end{array}$ \\
\hline $\begin{array}{l}\text { Type } 1 \text { patients } \\
\text { range }\end{array}$ & $\begin{array}{c}16 \pm 7 \\
6-29\end{array}$ & $19 / 21$ & $\begin{array}{c}10.0 \pm 5.2 \\
3.4-23.9\end{array}$ & $\begin{array}{l}8.7 \pm 1.5 \\
6.2-12.6\end{array}$ \\
\hline $\begin{array}{l}\text { Type } 2 \text { patients } \\
\text { range }\end{array}$ & $\begin{array}{l}58 \pm 12 \\
37-79\end{array}$ & $16 / 9$ & $\begin{array}{l}9.7 \pm 4.0 \\
4.5-22.4\end{array}$ & $\begin{array}{l}9.0 \pm 1.3 \\
6.9-11.8\end{array}$ \\
\hline $\begin{array}{l}\text { Control subjects } \\
\text { range }\end{array}$ & $\begin{array}{l}49 \pm 8 \\
25-65\end{array}$ & $130 / 25$ & $\begin{array}{l}5.3 \pm 0.5 \\
2.9-6.1\end{array}$ & \\
\hline
\end{tabular}

\section{Preparation of glycated human serum albumin}

A sample of $250 \mathrm{mg}$ of human serum albumin (HSA) (PENTEX Fraction V, Miles Lab., Naperville, Ill, USA) was dissolved in $5 \mathrm{ml}$ of phosphate-buffered saline solution containing $25 \mathrm{mg}$ of D-glucose and sterilized by filtration through a Millipore filter (pore size, $0.22 \mu \mathrm{m}$, Millipore Corp, Bedford, Mass, USA). The mixture was kept at $37^{\circ} \mathrm{C}$, and portions were collected on days 14 and 47 for assay of GA by the HPLC method.

\section{Collection of glycated albumin fractions}

In the HPLC analysis of serum samples, the fractions corresponding to GA (peak 2 in the second chromatogram in Fig.1) and non-GA (peak 1 in the second chromatogram in Fig. 1), respectively, were collected for measurement of glycated proteins by radioimmunoassay. 


\section{Subjects}

Blood was obtained after an overnight fast, from 40 patients with Type 1 (insulin-dependent) diabetes, 25 patients with Type 2 (noninsulin-dependent) diabetes and 155 healthy control subjects. The clinical characteristics of the subjects are shown in Table 2. The subjects consisted of patients attending the outpatient clinics of Tokushima University Hospital and Osaka University Hospital and healthy university personnel. To evaluate the diurnal variation of GA values, we obtained blood samples from 15 diabetic patients before and $2 \mathrm{~h}$ after each meal and at midnight. All subjects gave informed consent to participate in the study.

Serum was separated by centrifugation and stored at $-20^{\circ} \mathrm{C}$ until use.

\section{Other analytical methods}

Blood glucose was measured by the glucose oxidase method and $\mathrm{HbA}_{1 \mathrm{c}}$ by HPLC [13]. Immunoreactive glycated proteins were determined by a slight modification of the radioimmunoassay reported previously 14]. The procedure involves the specific reaction of ${ }^{125}$ Ilabelled monoclonal antibody to reduced bovine glycated low density lipoprotein with reduced glycated proteins bound to Coomassie Brilliant Blue coated beads together with nonglycated proteins. The fructosamine assay was performed in a Cobas Bio-centrifugal analyzer [15] with commercial reagents (F.Hoffmann-LaRoche, Basal, Switzerland).

\section{Statistical analysis}

Data are presented as means \pm SD. Student's t-test was used for statistical analyses.

\section{Results}

\section{Analytical studies}

Effect of incubation with glucose on the percentage of glycated albumin. The percentages of GA were $22 \%$, $39 \%$ and $50 \%$ on days 0,14 and 47 of incubation, respectively. Thus the percentage of GA increased during the incubation.

Concentrations of immunoreactive glycated protein in pooled fractions. The concentrations of immunoreactive glycated proteins in the pooled fractions of GA and nonGA were 12.5 and $0.14 \mathrm{nmol} / \mathrm{mg}$ protein respectively.

Diurnal variations in serum $G A$, fructosamine, glucose and protein concentrations. Figure 2 shows the diurnal variations of the mean serum GA, glucose and protein concentrations in 15 diabetic patients. Because of great individual variation in the values of these parameters, the values at the indicated times are expressed as percentages of those before breakfast. Changes in the mean percentage of GA during the test period were quite small, being $101.9 \pm 3.4 \%$ at most $2 \mathrm{~h}$ after dinner, whereas the serum glucose level fluctuated markedly with a maximum of $178.1 \pm 56.6 \%$ after dinner. Changes in the mean percentage level of serum fructosamine were also not marked, ranging from $99.3 \pm 6.3 \%$ to $103.9 \pm 5.7 \%$. The variability of values in the seven samples from each patient during the test period evaluated as the coefficient of variation $(\mathrm{CV})$, was $2.02 \pm 0.65 \%$ for GA, which was significantly smaller than that of $4.33 \pm 2.0 \%$ for fructosamine $(p<0.001)$. This intra-patient variability of GA was roughly within the limits of analytical variability. Figure 3 shows the correlation between the values for GA and fructosamine in these samples. The correlation was significant $(r=0.93, p<0.001)$.

\section{Clinical studies}

We next used this method for measuring the GA levels in three groups of subjects (Fig. 4). A group of 155 normal subjects had a mean GA level of $20.2 \pm 1.6 \%$ (range 17.2-23.4\%). This value was significantly lower $(p<0.001)$ than the mean serum GA values in two groups of diabetic patients $(39.6 \pm 5.4 \%$ in Type 1 and $39.4 \pm 5.9 \%$ in Type 2 patients). In addition, the diabetic patients had greater spread of values than the

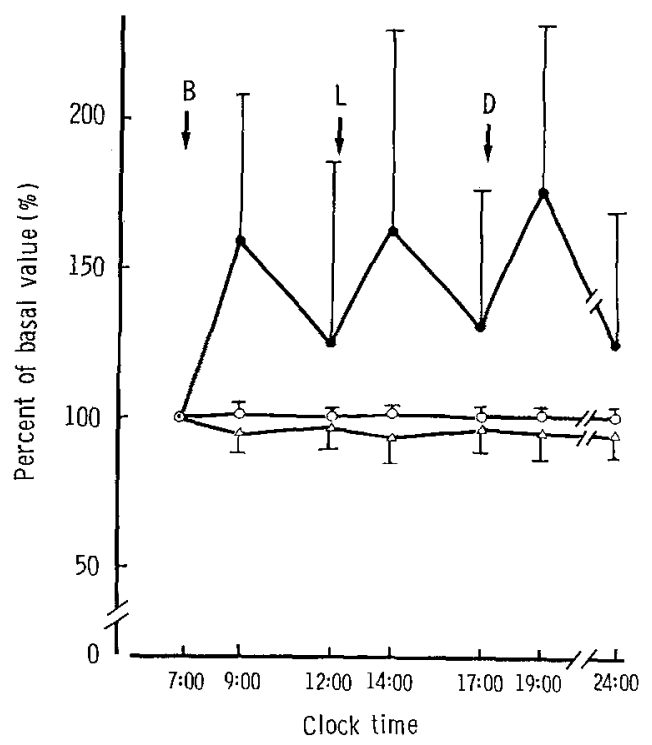

Fig. 2. Diurnal variations of mean serum glycated albumin $(\mathrm{O}-\mathrm{O})$, glucose $(-\mathrm{C})$ and protein $(\Delta-\Delta)$ concentrations in 15 diabetic patients. Values at the indicated times are expressed as percentages of those before breakfast. B, L and $D$ indicate breakfast, lunch and dinner, respectively

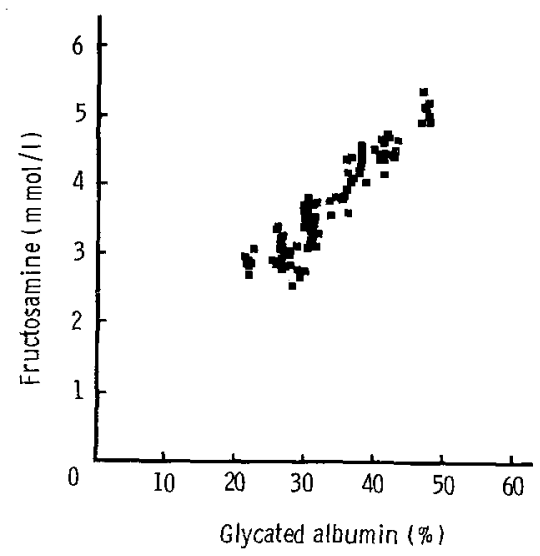

Fig.3. Correlation between glycated albumin and fructosamine levels in serum samples. Serum samples were obtained from 15 diabetic patients before and $2 \mathrm{~h}$ after each meal and at midnight. $(r=0.93, p<0.001$, correlation line; $\mathrm{y}=0.095 \mathrm{x}+0.527)$ 


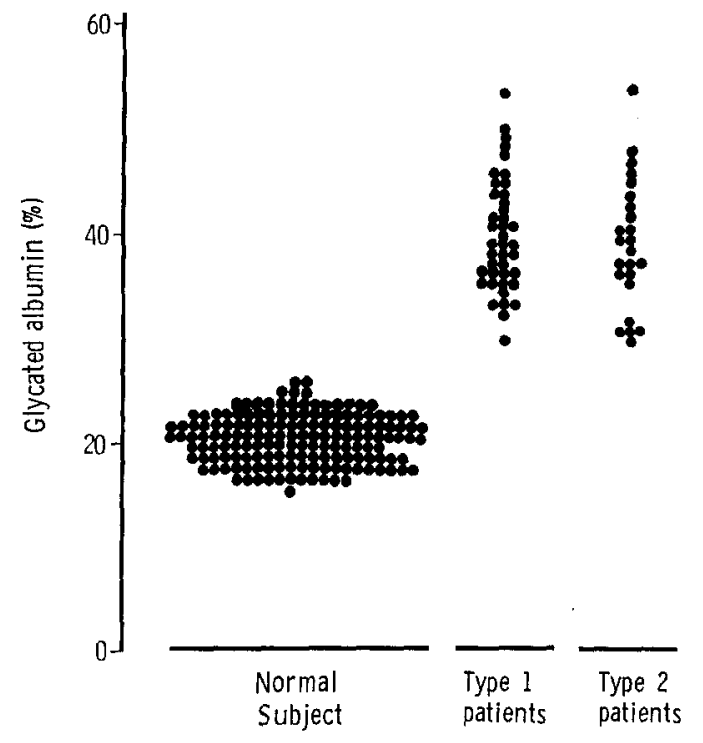

Fig.4. Fasting serum glycated albumin levels in 155 normal subjects and 40 Type 1 (insulin-dependent) and 25 Type 2 (non-insulin-dependent) diabetic patients. Clinical data on these subjects are given in Table 2

normal subjects. There was no overlap of the values in diabetic and control subjects.

A clear correlation was found between the GA and $\mathrm{HbA}_{1 \mathrm{c}}$ levels in all 65 diabetic patients $(r=0.60)$, and the correlation was greater $(r=0.76)$ when the subjects were limited to patients with Type 2 diabetes.

\section{Discussion}

The HPLC method reported here for measurement of glycated albumin is rapid and precise, requires a small sample, and can be automated. The separation of glycated from nonglycated protein depends on the interaction of the cis-diol groups of glycosyl moieties of the nonglycated protein with boronic acid [16]. As anticipated from the principle of the method, GA values appeared not to be influenced by the presence of a labile glycated fraction (the aldimine before rearrangement to the stable ketoamine), judging from the finding that the GA levels of samples obtained at different times of the day did not change despite remarkable fluctuation of the blood glucose level at the corresponding times (Fig. 2). On chromatography on the boronate column, Column II, the albumin preparation gave three distinct peaks, peak 1, 2 and 3 (Fig.1). The materials in peaks 1 and 2 were albumin, while that in peak 3 was not albumin but probably IgG and other components, judging from the elution positions of authentic albumin, IgG and transferrin. Radioimmunoassay of glycated protein showed that immunoreactive glycated protein was present exclusively in peak 2 , with a negligible amount in peak 1 , thus confirming that the affinity matrix separated the glycated form from the non-glycated form. These results, together with the finding that the ratio of peak 2 to peak 1 increased during incubation of HSA with glucose, indicate that the material in peak 1 was not glycated and that glycated albumin was eluted in peak 2. However, the present study does not exclude the possibility that some non-glycated albumin was present in peak 2 . Based on a value of GA, of $12.5 \mathrm{nmol} / \mathrm{mg}$ protein, $87 \%$ of the albumin molecules in peak 2 were glycated, assuming that nonenzymatic glycation of HSA occurred at one site [17], suggesting that the material in peak 2 was contaminated with about $10 \%$ of the non-glycated form. This might be one reason why our GA values for normal subjects were higher than those reported previously, though reported values range widely from $1.5 \%$ [11] to $15 \%$ [18], with one exceptional value of $27 \%$ [19]. There is a report [20] that the amount of glycation of albumin is $0.37 \mathrm{~mol} / \mathrm{mol}$ protein, that is, $37 \%$ when measured with the methods which are rigorous and more quantitative in character. If this is the case, any methods for glycated albumin reported so far merely measure a part of its amount. In any case, the values of glycated albumin should be confirmed by an independent methodology, which has not been consistently done.

Previous methods used to quantify glycated total protein and albumin were less precise than the present affinity chromatographic method, with $\mathrm{CV}$ values ranging from $5 \%$ to $14.4 \%[9,11,12,18]$ whereas that in the present method ranged from $0.7 \%$ to $4.9 \%$. Values in many of the methods used to quantify glycated haemoglobin, including the affinity-chromatographic procedure, are affected by fluctuations in temperature $[1,21]$. This is also true for affinity-chromatographic determination of glycated albumin and glycated total protein. We maintained both columns at $30^{\circ} \mathrm{C}$ by immersing them in a water bath. Besides the temperature, other conditions, such as the pressure applied to the columns and the flow rate of eluent could also be kept constant easily in the HPLC system. These constant conditions may have contributed to the high precision achieved.

The methods for quantifying serum glycated albumin reported hitherto $[9,11,12,18]$ involve prior separation of albumin from other serum proteins by methods such as DEAE-cellulose and/or affinity chromatography on Affi-Gel Blue (Bio-Rad Lab., Richmond, Calif, USA). By connecting the boronate column with the anion exchange one of Asahipak ES$502 \mathrm{~N}$, which can separate albumin from other serum components almost completely, our method does not require another step for purification of albumin. Thus, the method is labour-saving and can be automated. Because free glucose competes with protein-bound glucose for boronic acid binding sites, decreasing the binding of protein-bound glucose [12], free glucose must be removed. This has been done by chromatography on Sephadex G-25 or dialysis, but in our method, values were not influenced by the presence of glucose in serum samples, probably because the glucose was diluted and/or removed during anion exchange chromatography. 
As mentioned above, quantitation of glycation of serum proteins by the various methods used so far is too time-consuming to be used routinely. The fructosamine test [22] was recently developed to facilitate quantitation of serum protein glycation. The values for GA measured by the present method were significantly correlated with those for fructosamine (Fig.3), suggesting that these analytes are indices of similar aspects of glycaemic control. However, estimation of protein glycation by fructosamine assay in seven serum samples obtained from a subject during the 17-h test period gave more variable results (CV; $4.33 \pm 2.0 \%)$ than those obtained by the present method (CV; $2.02 \pm 0.65 \%)$. As already pointed out [23], values for fructosamine concentration are influenced by the protein concentrations and also by the lipid and bilirubin contents of samples, whereas these substances did not affect GA determinations by the present method (data not shown).

The present study showed that the serum GA level was significantly higher in diabetic patients than in normal control subjects. This difference confirms that glycated albumin is an indicator of glycaemic control. The absence of overlap between the GA levels in normal subjects and diabetic patients suggests that GA may be a more sensitive index than other parameters such as $\mathrm{HbA}_{1 \mathrm{c}}$, as already reported by others [24]. We are now testing this possibility by using these parameters in screening tests for detection of diabetes mellitus.

GA levels correlated better with $\mathrm{HbA}_{1 \mathrm{c}}$ in patients with Type 2 diabetes than in those with Type 1 diabetes, in whom glycaemic control is less stable. GA probably responds more quickly than $\mathrm{HbA}_{1 \mathrm{c}}$ to changes in glycaemic control because albumin has a shorter half-life and may have a greater tendency to become glycated [17]. Values of GA should provide additional useful information on diabetic control in unstable diabetic patients in whom the $\mathrm{HbA}_{1 \mathrm{c}}$ level appears to change too slowly to reflect rapid fluctuations in blood glucose level.

\section{References}

1. Mayer TK, Freedman ZR (1983) Protein glycosylation in diabetes mellitus: a review of laboratory measurements and of their clinical utility. Clin Chim Acta 127: 147-184

2. Kirschenbaum DM (1984) Glycosylation of proteins: its implications in diabetic control and complications. Pediatr Clin N Amer 31: $611-621$

3. Dolhofer R, Wieland OH (1979) Glycosylation of serum albumin: elevated glycosyl-albumin in diabetic patients. FEBS Lett 103: 282-286

4. Guthrow CE, Morris MA, Day JF, Thorpe SR, Baynes JW (1979) Enhanced nonenzymatic glycosylation of human serum albumin in diabetes mellitus. Proc Natl Acad Sci USA 76: 4258-4261

5. Kennedy AL, Kandell TW, Merimee TJ (1979) Serum proteinbound hexose in diabetes. The effect of glycemic control. Diabetes 28: 1006-1010

6. McFarland XF, Catalano EW, Day JF, Thorpe SR, Bayness JW (1979) Nonenzymatic glycosylation of serum proteins in diabetes mellitus. Diabetes 28: 1011-1014

7. Kennedy AL, Merimee TJ (1981) Glycosylated serum protein and hemogiobin $A_{1}$ levels to measure control of glycemia. Ann Intern Med 95: 56-58

8. Yue DK, Morris K, McLennan S, Turtle JR (1980) Glycosylation of plasma protein and its relation to glycosylated hemoglobin in diabetes. Diabetes 29: 296-300

9. Nelson DM, Barrows HJ, Clapp DH, Ortman-Nabi J, Whitehurst RM (1985) Glycosylated serum protein levels in diabetic and nondiabetic pregnant patients: an indicator of short-term glycemic control in the diabetic patient. Am J Obstet Gynecol 151: $1042-1047$

10. Morris MA, Grandis AS, Litton J (1985) The correlations of glycosylated serum protein and glycosylated hemoglobin concentrations with blood glucose in diabetic pregnancy. Am J Obstet Gynecol 153: 257-260

11. Ziel FH, Davidson MB (1987) The role of glucosylated serum albumin in monitoring glycemic control in stable insulin-requiring diabetic out-patients. J Clin Endocrinol Metab 64: 269-273

12. Yatscoff RW, Tevaarwerk GJM, MacDonald JC (1984) Quantification of nonenzymically glycated albumin and total serum protein by affinity chromatography. Clin Chem 30: 446-449

13. Davis JE, McDonald JM, Jarett L (1978) A high-performance liquid chromatography method for hemoglobin $\mathrm{A}_{1 \mathrm{c}}$. Diabetes 27 : 102-107

14. Ohe Y, Matsuura M, Nakajima Y, Shin S, Hashimoto F, Hirota M, Shima K (1987) Radioimmunoassay of glycosylated albumin with monoclonal antibody to glucitol-lysine. Clin Chim Acta 169: $229-238$

15. Baker JR, Metcalf PA, Johnson RN, Newan D, Rietz P (1985) Use of protein-based standards in automated colorimetric determinations of fructosamine in serum. Clin Chem 31: 1550-1554

16. Mallia AK, Hermanson GT, Krohn RI, Fujimoto EK, Smith PK (1981) Preparation and use of a boronic acid affinity support for separation and quantitation of glycosylated hemoglobins. Anal Lett 14: 649-661

17. Garlick RL, Mazer JS (1983) The principal site of nonenzymatic glycosylation of human serum albumin in vivo. J Biol Chem 258: 6142-6146

18. Day JF, Thorpe SR, Baynes JW (1979) Nonenzymatically glucosylated albumin. J Biol Chem 254: 595-597

19. Kverneland A, Feldt-Rasmussen B, Vidal P, Welinder B, BentHansen L, Soegaard U, Deckert T (1986) Evidence of changes in renal charge selectivity in patients with Type 1 (insulin-dependent) diabetes mellitus. Diabetologia 29:634-639

20. Olufemi S, Talwar D, Robb DA (1987) The relative extent of glycation of hemoglobin and albumin. Clin Chim Acta 163: 125-136

21. Yatscoff RW, Tevaarwerk GJM, Clarson C, Warnock L (1983) Evaluation of an affinity chromatographic procedure for the determination of $\mathrm{HbA}_{1}$. Clin Biochem 16: 291-295

22. Johnson RN, Metcalf PA, Baker JR (1982) Fructosamine: a new approach to the estimation of serum glycosylprotein: an index of diabetic control. Clin Chim Acta 127: 87-95

23. Flückiger R, Woodtli T, Berger W (1987) Evaluation of the fructosamine test for the measurement of plasma protein glycation. Diabetologia 30: 648-652

24. Schleicher ED, Gerbitz KD, Dolhofer R, Reindl E, Wieland $\mathrm{OH}$, Edelmann E, Haslbeck M, Kemmler W, Walter H, Mehnert H (1984) Clinical utility of nonenzymatically glycosylated blood proteins as an index of gluycose control. Diabetes Care 7: $548-556$

Received: 21 March 1988

and in revised form: 10 June 1988

Dr. K. Shima

Department of Laboratory Medicine

Tokushima University Medical School

Kuramoto-cho

3-chome, 18-15

Tokushima 770

Japan 